\title{
LOX wt Allele
}

National Cancer Institute

\section{Source}

National Cancer Institute. LOX wt Allele. NCI Thesaurus. Code C50891.

Human LOX wild-type allele is located in the vicinity of $5 \mathrm{q} 23.2$ and is approximately $12 \mathrm{~kb}$ in length. This allele, which encodes protein-lysine 6-oxidase protein, is involved in initiating the cross-linking of collagens and elastin. LOX gene expression is associated with both metastasis and poor patient survival in several types of cancer including breast and head and neck cancers. 